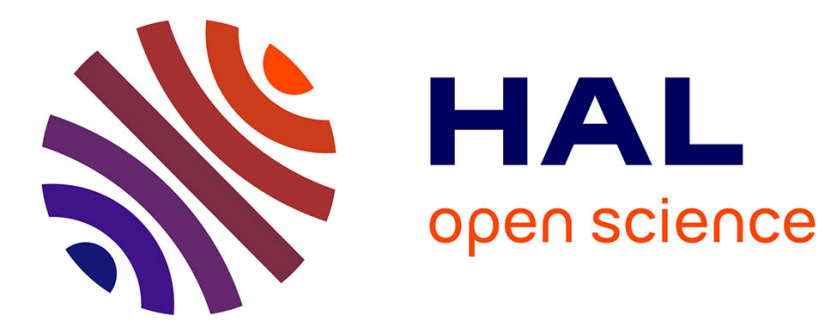

\title{
Oral language, written language and language awareness
}

Christophe Parisse

\section{To cite this version:}

Christophe Parisse. Oral language, written language and language awareness. Journal of Child Language, 2002, 29, pp.478-481. halshs-00102688

\section{HAL Id: halshs-00102688 \\ https://shs.hal.science/halshs-00102688}

Submitted on 2 Oct 2006

HAL is a multi-disciplinary open access archive for the deposit and dissemination of scientific research documents, whether they are published or not. The documents may come from teaching and research institutions in France or abroad, or from public or private research centers.
L'archive ouverte pluridisciplinaire HAL, est destinée au dépôt et à la diffusion de documents scientifiques de niveau recherche, publiés ou non, émanant des établissements d'enseignement et de recherche français ou étrangers, des laboratoires publics ou privés. 
Oral language, written language and language awareness

Christophe Parisse

INSERM, Paris, France

Ravid and Tolchinsky's paper draws a comprehensive picture of the fact that literacy is a lengthy developing process involving many linguistic factors which sometimes begins even before school age and lasts until adulthood. I very much appreciated the breadth and thoroughness of Ravid and Tolchinsky's paper and, in particular, the fact that they have taken the relationship between oral language and literacy into account. It seems to me that this is rarely the case in current linguistic theories and I would like to offer a few comments on some of the consequences that a serious approach to literacy development would have on the studies of oral language and literacy both, and on linguistic theories themselves as well.

As pointed out in Ravid and Tolchinsky's paper, oral and written languages develop together and their structural properties in the adult's mind would not be the same had they developed separately, so that a model of the literacy development should not just be a model of the written language development, but of both modalities. This has two interesting corollaries: 1) the development of oral language is not achieved at age six, but goes on to be profoundly influenced by literacy development; 2) linguistic theory should take oral language, written language, and how they modify each other during development into account.

Paradoxically, the fact that oral and written languages have great impact one on the other suggests that they are governed by different principles and rely on different types of knowledge. Ravid and Tolchinsky mention some of the structural differences between unconscious mastery of oral language and literacy development when they point out that "naïve language users ... are not aware of NP structures or verb arguments", and that "sideby-side with the development of implicit language knowledge ..., language users develop another facet of explicit and analytic awareness". Structural differences between oral and written language have also been studied and described elsewhere (see for example, Halliday, 1985; Miller \& Weinert, 1998), but I would like to go one step further and propose the following. Oral language is a basically unconscious process that would be better modelled by data-oriented, probabilistic or connectionist, exemplar-based, models such as those developed in computer linguistics (see for example, Barlow \& Kemmer, 2000; Bod, 1998; Daelemans, 1999), whereas written language is basically a conscious process that can be adequately modelled by rule-liked, non-probabilistic, symbolic, category-based approaches of linguistic theory (e.g. Government and Binding, Lexical Functional Grammar, Head-driven Phrase Structure Grammar, etc.). Interferences between oral and written language appear during development as oral language starts to include some conscious processing and written language becomes partly automatic and unconscious.

It is often pointed out that differences between oral and written language come from memory and processing limitations, or from the ability to edit, rewrite and restructure texts. I propose that the first and major reason for these differences is the development of language awareness and of the ability to re-interpret the language signal. Memory and processing limitations also apply to written language, even if not as severely, as written information can be retrieved as many times as necessary. However, taking another conscious look at what has just been perceived is impossible with oral language. Perception of written signal first occurs through unconscious processing until some interpretation is achieved which can be used to consciously re-analyse the written data. The initial data, the signal, which interpretation is highly dependent of the perception and language context, now appears as an 'object' clearly defined and focused in the reader's mind - the sharper the consciousness, the clearer the object. At that point, the object will be linked to the written word in the reader's mind. Any further reasoning about language structures or properties will be performed using these 
clearly-defined objects/written-words. Thinking about language has become symbolic, with clear and non-ambiguous symbols highly suitable for producing symbolic and rule-like reasoning. Furthermore, when consciously analysing written material, relevant unconscious material is not taken into account because of its different nature. Over-generalisation of rules is thus a logical consequence of this process because reasoning is performed with a reduced set of data. General properties are put forward and local specific characteristics ignored. Reanalysis of written material can be performed at any level -morphology, syntax, semantics, and pragmatics- because it is possible to focus consciously on any specific element.

All this is impossible with oral language because of the non-permanence of the speech signal. The signal is lost and only its interpretation remains, making both identification between the speech signal and the language interpretation and conscious rule-like reasoning with the speech signal impossible. The resulting interpretation of the oral signal can be conscious, but conscious perception of the formal characteristics of oral language signals is highly problematic, and requires a level of linguistic expertise beyond that which most people achieve. This expertise is usually acquired concomitantly with literacy, as is described in Ravid and Tolchinsky's paper. This makes morphology and syntax special because their conscious analysis is easy only in written language. The very length of the historical processes that made linguistics a science argues in the same direction, especially the high correlation between the history of the awareness of language structure and the history of literacy (see Auroux, 1989; Harris, 1980; Ong, 1982), to the point where the existence of metalinguistic awareness without written language becomes questionable (see Auroux, 1989, p. 21). It is thus logical to find that linguistic theories are well suited to the study of written language, and that classical linguistic theories are symbolic: they were developed through conscious analysis of language material and with the help of written material.

An important corollary of the remarks above is that it is virtually impossible to analyse child language using adult language theories and descriptions. Adult knowledge of language is a hybrid of symbolic and sub-symbolic/probabilistic processes, whereas child knowledge is still only sub-symbolic/probabilistic. This is why Ravid and Tolchinsky's proposals are so important. A better understanding of what is involved in the acquisition of literacy is necessary to be able to go backwards from adult to child knowledge of language. It is also crucial to take into account the mutual and permanent influences between unconscious and conscious processes that govern the development of language and literacy. This should lead the way to developing non-symbolic linguistic theories more suited to studying and describing child language, and to elaborating hybrid language models -both symbolic and probabilisticfor the adult language.

Auroux, S. (1989). Introduction. In S. Auroux (Ed.), Histoire des idées linguistiques . Sprimont: Mardaga.

Barlow, M., \& Kemmer, S. (Eds.). (2000). Usage based models of language. Stanford, CA: CSLI Publications.

Bod, R. (1998). Beyond grammar: An experience-based theory of language. Stanford, CA: CSLI Publications.

Daelemans, W. (1999). Memory-based language processing: Introduction to the special issue. JETAI, 11(3), 287-292.

Halliday, M. A. K. (1985). Spoken and Written Language. Geelong: Deakin University Press.

Harris, R. (1980). The language makers. London: Duckworth.

Miller, J., \& Weinert, R. (1998). Spontaneous Spoken Language. Oxford: Clarendon Press. 
Ong, W. J. (1982). Orality and literacy : the technologizing of the word. London: Methuen. 